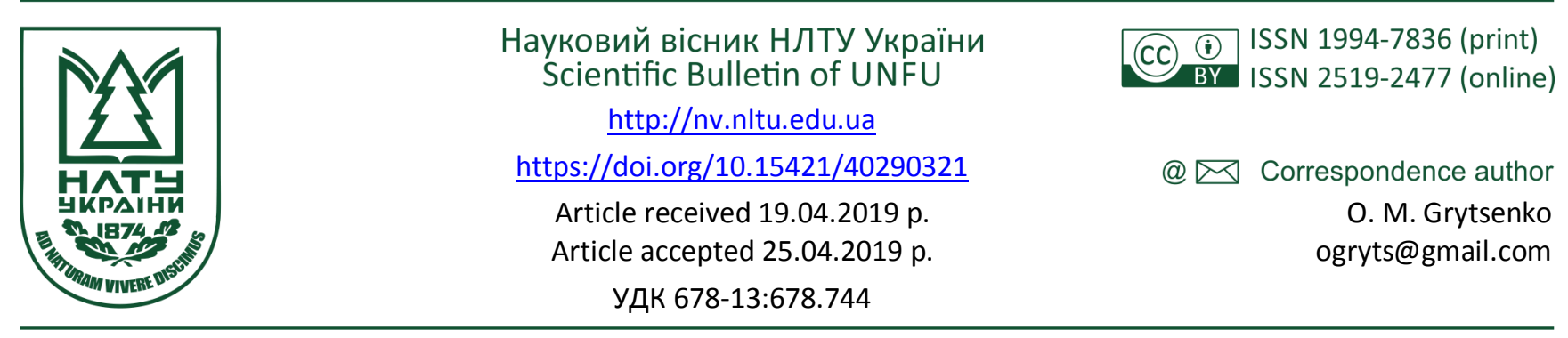

А. В. Похмурська ${ }^{1}$, О. М. Гриценко ${ }^{1}$ О. В. Суберляк ${ }^{1}$, Н. Є. Горбенко

${ }^{1}$ Національний університет "Львівська політехніка", м. Львів, Украӥна

${ }^{2}$ Національний лісотехнічний університет Украӥни, м. Львів, Украӥна

\title{
ТЕРМОМЕТРИЧНІ ДОСЛІДЖЕННЯ ПОЛІМЕРИЗАЦІЇ 2-ГІДРОКСІЕТИЛМЕТАКРИЛАТУ В ПРИСУТНОСТІ ПОЛІВІНІЛПІРОЛІДОНУ $З$ ОДНОЧАСНИМ ВІДНОВЛЕННЯМ ЙОНІВ НІКЕЛЮ
}

\begin{abstract}
За допомогою термометричного методу досліджено кінетику виділення тепла під час полімеризації композицій на основі 2-гідроксіетилметакрилату (ГЕМА) та полівінілпіролідону (ПВП), ініційованої пероксидом бензоїлу з одночасним відновленням $\mathrm{Ni}^{2+}$. Для відновлення $\mathrm{Ni}^{2+}$ використано окисно-відновну систему нікелю сульфат натрію гіпофосфіт у лужному середовищі. Оцінено вплив складу вихідної композиції, вмісту розчинника, початкової температури полімеризації, концентрації окисника та відновника на кінетичні параметри полімеризації - час початку гелеутворення, час досягнення максимальної температури екзотермії, область гель-ефекту та максимальну температуру екзотермії. Встановлено, що у випадку ГЕМА/ПВП композицій полімеризація у присутності пероксиду бензоїлу відбувається з високою швидкістю вже за температури $50^{\circ} \mathrm{C}$. Доведено, що використання комплексного ініціатора, який складається з сульфату заліза (II) та пероксиду бензоїлу, дає можливість здійснювати полімеризацію ГЕМА/ПВП композицій за кімнатної температури та 3 максимальною температурою екзотермії, яка забезпечує хімічне осадження металу. Виявлено, що температура, до якої нагрівається реакційне середовище, може бути достатньою для перебігу хімічної реакції відновлення $\mathrm{Ni}^{2+}$.

Ключові слова: екзотермічна полімеризація; температура екзотермії; кінетика полімеризації; гель-ефект; металонаповнені полімерні композити.
\end{abstract}

Вступ. Сьогодні підвищений інтерес науковців та дослідників проявляється до нового класу матеріалів полімерних гідрогелів, наповнених мікро- та нанорозмірними частинками металічної, діелектричної або напівпровідникової природи (Schexnailder \& Schmidt, 2009). Особливої уваги заслуговують композиційні матеріали, які містять частинки неорганічної природи метали та їхні оксиди (Nicolais \& Carotenuto, 2004). Meталонаповнені гідрогелі проявляють специфічні властивості, які можуть змінюватись залежно від вмісту вологи, тиску, температури та $\mathrm{pH}$ середовища, що відкриває нові можливості їх використання. Головна проблема, яка виникає під час створення таких матеріалів, полягає у способі введення наповнювача у полімерну матрицю. Принципово новим методом одержання металонаповнених полімерних гідрогелевих матеріалів $є$ одержання частинок металу на стадії синтезу полімеру. Розроблений метод $\epsilon$ привабливим як з практичного, так і $з$ наукового погляду через те, що дає можливість отримати частинки наповнювача нано- та мікророзмірів, досягнути кращого, рівномірного їх розподілу та одержати композиційні матеріали з ізотропними властивостями.

Наша робота є одним з етапів розроблення гідрогелевих нікельнаповнених матеріалів на основі кополімерів 2-гідроксіетилметакрилату (ГЕМА) 3 полівінілпіролідоном (ПВП) методом суміщення процесів полімеризації та хімічного осадження металу.

Відомо, що формування структури, властивості, а також технологічні особливості одержання полімерів, зокрема і металонаповнених, залежать від кінетичних закономірностей полімеризаційного процесу. Особливо важливим $\epsilon$ вивчення закономірностей полімеризації, яка відбувається одночасно 3 хімічним відновленням йонів металів та встановлення взаємного впливу двох різних за природою хімічних процесів (Grytsenko et al., 2018). Однак, через багатокомпонентність вихідної реакційної композиції, виділення газоподібних продуктів під час осадження нікелю, присутність у реакційній

Інформація про авторів:

Похмурська Анна Володимирівна, аспірант, кафедра хімічної технології переробки пластмас. Email: a.gaiduk92@gmail.com; https://orcid.org/0000-0003-3722-0616

Гриценко Олександр Миколайович, д-р техн. наук, доцент, кафедра хімічної технології переробки пластмас. Email: ogryts@gmail.com; https://orcid.org/0000-0001-8578-4657

Суберляк Олег Володимирович, д-р хім. наук, професор, завідувач кафедри хімічної технології переробки пластмас. Email: suberlak@polynet.lviv.ua; https://orcid.org/0000-0002-6046-5972

Горбенко Наталія Євгенівна, канд. с.-г. наук, доцент, кафедра ботаніки, деревинознавства та недеревних ресурсів лісу. Email: nata.horbenko@gmail.com; https://orcid.org/0000-0002-6053-6582

Цитування за ДСту: Похмурська А. В., Гриценко О. М., Суберляк О. В., Горбенко Н. Є. Термометричні дослідження полімеризації 2-гідроксіетилметакрилату в присутності полівінілпіролідону з одночасним відновленням йонів нікелю. Науковий вісник Нлту України. 2019, т. 29, № 3. С. 99-103.

Citation APA: Pokhmurska, A. V., Grytsenko, O. M., Suberlyak, O. V., \& Gorbenko, N. Ye. (2019). Thermometric investigations of 2hydroxyethylmethacrylate polymerization at the presence of polyvinylpyrrolidone with simultaneous nickel ions reduction. Scientific Bulletin of UNFU, 29(3), 99-103. https://doi.org/10.15421/40290321 
системі хімічних реагентів та продуктів окисно-відновних реакцій, конкретне визначення кінетичних параметрів полімеризації є утрудненим. Водночас полімеризація ГЕМА в присутності ПВП відбувається за радикальним механізмом через стадію утворення комплексу з перенесенням заряду (КПЗ) (Suberlyak \& Skorokhoda, 2018) і є процесом екзотермічним - відбувається з гельефектом, що викликає саморозігрівання системи (Suberlyak, Kurylo \& Sheketa, 1982). Наявність тепловиділення під час екзотермічної реакції полімеризації забезпечує можливість використання термометричного методу для оцінювання кінетичних закономірностей кополімеризації ГЕМА з ПВП у присутності окисно-відновної системи. Окрім цього, можливо передбачити, що тепло, яке виділяється у процесі полімеризації, може бути джерелом енергії, необхідної для хімічного відновлення $\mathrm{Ni}^{2+}$ і таким способом забезпечить зменшення температури відновлення, а отже, і початкової температури полімеризації. Зменшення температури полімеризаційних та окисно-відновних процесів $є$ ефектом технологічним, оскільки зменшуються енергетичні витрати на одержання композиту. Тому доцільно дослідити екзотермічні ефекти, які супроводжують полімеризацію ГЕМА/ПВП композицій, що дасть змогу обгрунтувати температурний режим синтезу полімерів 3 одночасним відновленням $\mathrm{Ni}^{2+}$ та створити енергозберігаючої технології одержання металонаповнених полімерів.

Матеріали і методи дослідження. Для полімеризації використовували 2-гідроксіетилметакрилат (Sigma Chemical Co) та полівінілпіролідон (AppliChem $\mathrm{GmbH}$ ) високого очищення з ММ 12000, як ініціатор - пероксид бензоїлу (ПБ). ГЕМА переганяли у вакуумі (залишковий тиск $130 \mathrm{H} / \mathrm{m}^{2}, T_{\text {киn. }}=351 \mathrm{~K}$ ), ПВП сушили за $338 \mathrm{~K}$ у вакуумі 2-3 год, ПБ перекристалізовували 3 етанолу. Неорганічні солі (нікелю сульфат, натрію гіпофосфіт, феруму (II) сульфат, аргентуму нітрат) використовували марок ч.д.а.

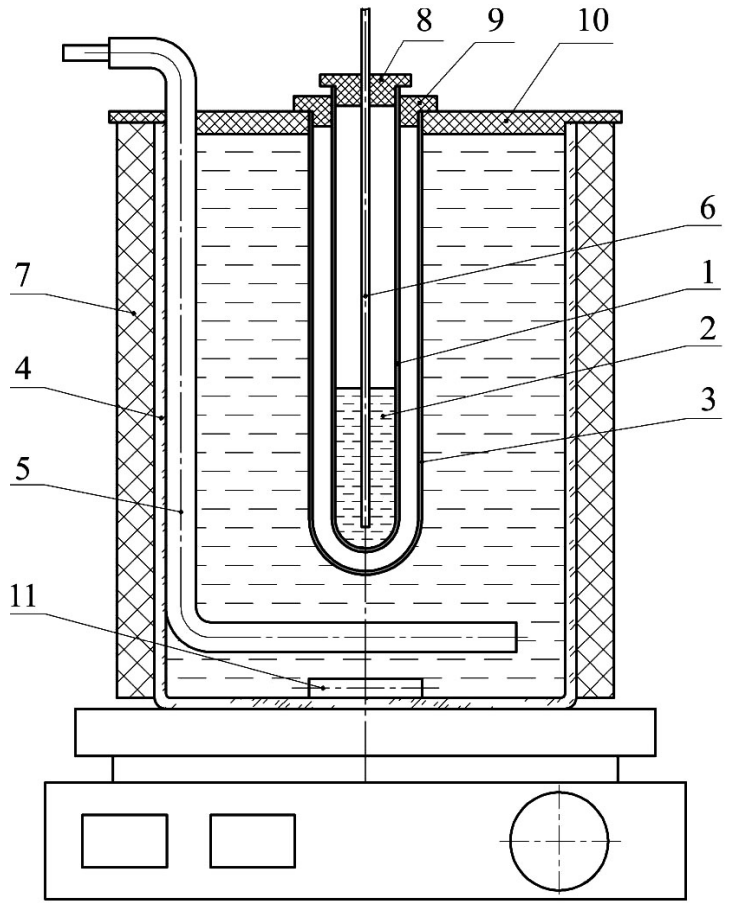

Рис. 1. Установка для здійснення термометричних досліджень: 1) реактор; 2) композиція; 3) ізоляційна сорочка; 4) водяний термостат; 5) електронагрівач; 6) термопара; 7) теплоізоляційний каркас; 8) кришка реактора; 9) кришка ізоляційної сорочки; 10) кришка водяного термостата; 11) магнітна мішалка
Зміну температури реакційного середовища під час реакції полімеризації досліджували термометричним методом за допомого реактора, який за своїми властивостями наближений до адіабатичного (рис. 1).

Для відновлення $\mathrm{Ni}^{2+}$ використовували окисно-відновну систему (OBC) $\mathrm{NiSO}_{4} / \mathrm{NaH}_{2} \mathrm{PO}_{2}$ ([NiSO 4$]$ : $\left[\mathrm{NaH}_{2} \mathrm{PO}_{2}\right]=1: 2,2$ моль/л). Використовували ОВС 3 активатором відновлення - нітратом срібла ([Ag$\left.\mathrm{NO}_{3}\right]=0,25$ г/л) у лужному середовищі 3 початковим $\mathrm{pH}=7,5-8$, який регулювали $25 \%$ розчином аміаку. Синтез здійснювали за початкової температури $\mathrm{T}_{0}=50^{\circ} \mathrm{C}$ (ініціатор - ПБ) та $\mathrm{T}_{0}=25^{\circ} \mathrm{C}$ (ініціатор ПБ/ $\left.\mathrm{FeSO}_{4}\right)$. Готували полімер-мономерну композицію (ПМК) з ініціатором ПБ (0,3 мас.\%) - за кімнатної температури в ГЕМА розчиняли необхідну кількість ПБ та ПВП до одержання гомогенної суміші. Окремо готували розчин $\mathrm{OBC}\left(\mathrm{P}_{\mathrm{OBC}}\right)$ - водний розчин окисника $\mathrm{NiSO}_{4}$ 3 відновником $\mathrm{NaH}_{2} \mathrm{PO}_{2} 3$ додаванням $\mathrm{FeSO}_{4}$ (0,01 мас.\%). ПМК та ОВС змішували і дозували $(V \kappa=5$ мл) в реактор 1 (див. рис. 1). Кінетичні закономірності полімеризації оцінювали за отриманими термометричними кривими, на яких були виділені характерні параметри (рис. 2).

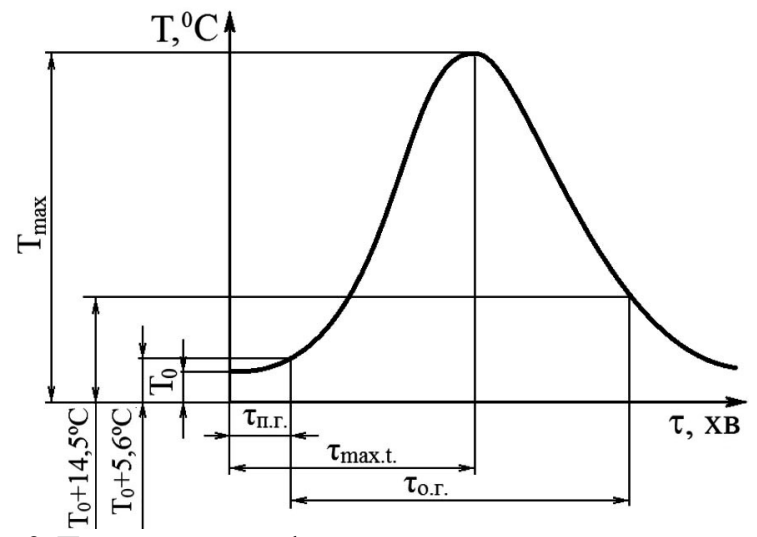

Рис. 2. Параметри гель-ефекту: $\tau_{\text {п.г. }}$ - час початку гелеутворення; $\tau_{\text {max.t. }}$ - час досягнення максимальної температури екзотермії; $\tau_{\text {о.г. }}$ - область гель-ефекту; $\mathrm{t}_{\max }$ - максимальна температура екзотермії

Результати досліджень та їх обговорення. Відомо, що кінетичні параметри полімеризації, розраховані на основі термометричних кривих, $є$ напівкількісними, а іноді тільки ілюстративними і використовуються для порівняльної характеристики мономерних або ініціювальних систем (Korolyov, Pavlov \& Berlin, 1959). Ocкільки дослідження в нашому випадку є порівняльними і необхідні для розроблення технології одержання металонаповнених ГЕМА-ПВП кополімерів та їх гідрогелів, використання термометричного методу для характеристики кінетичних параметрів гель-ефекту $є$ достатньо обгрунтованим.

На основі результатів попередніх робіт (Suberlyak, Skorokhoda \& Grytsenko, 2000) для досліджень вибрано композицію складу ГЕМА: ПВП $=90 \div 70: 10 \div 30$ мас.ч. 3 використанням $10 \div 50$ мас.ч. розчинника $\left(\mathrm{H}_{2} \mathrm{O}\right)$. Необхідність присутності розчинника у вихідній композиції зумовлена розчиненням у ньому окисника та відновника. Як ініціатор полімеризації використовували ініціатор радикального типу - пероксид бензоїлу (ПБ), вибір якого зумовлений його широким використанням для синтезу ГЕМА-ПВП кополімерів (Suberlyak, Kurylo \& Sheketa, 1982). Пероксид бензоїлу є ініціатором "гаря- 
чого затвердження" і використовується за температур 80-90 ${ }^{\circ} \mathrm{C}$ (Nikolayev, 1974). Однак встановлено, що у випадку ПВП-ГЕМА композицій полімеризація у присутності ПБ відбувається з високою швидкістю вже за температури $50{ }^{\circ} \mathrm{C}$. 3 огляду на це, в роботі за початкову температуру полімеризації приймали $\mathrm{T}_{0}=50^{\circ} \mathrm{C}$.

Концентрація ініціатора під час досліджень становила $0,1 \div 0,5$ мас.\%. За початкової температури $50{ }^{\circ} \mathrm{C}$ та вмісту ініціатора 0,1 мас.\% спостерігаємо тривалий індукційний період із подальшим гель-ефектом, який проявляється через 67 хв (табл. 1).

Табл. 1. Залежність параметрів гель-ефекту полімеризації ГЕМА/ПВП композицій від вмісту ініціатора ПБ

\begin{tabular}{|c|c|c|c|c|c|}
\hline $\begin{array}{l}\text { № } \\
\text { 3/ח }\end{array}$ & [ПБ], мас. \% & $\tau_{\text {n.z. }}, \mathrm{XB}$ & $\tau_{\text {T.max. }}, \mathrm{XB}$ & $\tau_{\text {o.z. }}, \mathrm{XB}$ & $T_{\text {макс }},{ }^{\circ} \mathrm{C}$ \\
\hline 1 & 0,1 & 67 & 86 & 28 & 116,8 \\
\hline 2 & 0,3 & 12 & 26 & 27 & 121,1 \\
\hline 3 & 0,5 & 8 & 23 & 24 & 124,5 \\
\hline
\end{tabular}

Примітка: ГЕМА:ПВП: $\mathrm{H}_{2} \mathrm{O}=80: 20: 10$ мас.ч.; $T_{0}=50^{\circ} \mathrm{C}$

Максимальна температура екзотермії у цьому випадку становить $116,8^{\circ} \mathrm{C}$ і досягається через 86 хв. У випадку збільшення концентрації ініціатора до 0,3 мас.

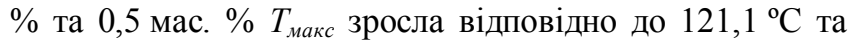
$124,5^{\circ} \mathrm{C}$ із зменшенням $\tau_{\text {max.t. }}$ - до 26 хв та 23 хв. Значно скорочується і час настання гель-ефекту. На основі аналізу та порівняння отриманих кінетичних параметрів полімеризації за різних концентрацій ПБ, для подальших досліджень вибрано вміст ініціатора 0,3 мас.\%.

Зменшення концентрації мономеру внаслідок розведення композиції розчинником закономірно спричинює падіння початкової швидкості полімеризації, про що свідчить зростання часу початку гель-ефекту та досягнення максимальної температури екзотермії із значним iii зменшенням (табл. 2.).

Табл. 2. Залежність параметрів гель-ефекту полімеризації ГЕМА/ПВП композицій від вмісту ПВП

\begin{tabular}{|c|c|c|c|c|c|}
\hline $\begin{array}{c}\text { № } \\
\text { 3/П }\end{array}$ & {$\left[\mathrm{H}_{2} \mathrm{O}\right]$, мас.ч. } & $\tau_{\text {п.г. }}$, хв & $\tau_{\text {Т.max., }}, \tau_{\text {ов.г., Хв }}$ & $\mathrm{T}_{\text {макс }},{ }^{\circ} \mathrm{C}$ \\
\hline 1 & 10 & 12 & 26 & 27 & 121,1 \\
\hline 2 & 25 & 16 & 34 & 28 & 96,8 \\
\hline 3 & 50 & 19,5 & 41 & 30 & 79,2 \\
\hline
\end{tabular}

Примітка: ГЕМА: ПВП = 80:20 мас.ч.; [ПБ] = 0,3 мас.\%; $T_{0}=50^{\circ} \mathrm{C}$

Збільшення вмісту води від 10 мас.ч. до 50 мас.ч. викликає зниження $T_{\text {макс }}$ від $121^{\circ} \mathrm{C}$ до $79^{\circ} \mathrm{C}$, а $\tau_{T \text {.max. }}$, відповідно, від 22 хв до 40 хв. Водночас необхідно відзначити, що область гель-ефекту змінюється незначно. Експериментально встановлено, що присутність навіть невеликого вмісту ОВС значно впливає на швидкість перебігу процесу полімероутворення - одночасне здійснення реакцій хімічного відновлення $\mathrm{Ni}^{2+}$ та полімеризації викликає зростання $\tau_{n .2 .}, \tau_{T . m a x}, \tau_{\text {o.z. }}$ та зменшення $T_{\text {макс }}$ (табл. 3, поз. 1, 2).

Табл. 3. Вплив процесу хімічного відновлення $\mathrm{Ni}^{2+}$ на параметри гель-ефекту полімеризації ГЕМА/ПВП композицій

\begin{tabular}{|c|c|c|c|c|c|c|c|c|}
\hline \multirow[b]{2}{*}{$\begin{array}{l}\text { № } \\
\text { 3/ח }\end{array}$} & \multicolumn{4}{|c|}{ Окисно-відновна система } & \multirow[b]{2}{*}{$\begin{array}{c}\tau_{\text {n.2., }} \\
\mathrm{XB}\end{array}$} & \multirow[b]{2}{*}{$\begin{array}{c}\tau_{T . m a x} \\
\text { XB }\end{array}$} & \multirow[b]{2}{*}{$\begin{array}{c}\tau_{\text {o.z., }} \\
\mathrm{XB}\end{array}$} & \multirow[b]{2}{*}{${ }^{T_{\text {макс }}}$} \\
\hline & $\begin{array}{c}\text { окис- } \\
\text { ник }\end{array}$ & $\begin{array}{c}\text { вміст } \\
\text { окисни- } \\
\text { ка, } \\
\text { моль/л }\end{array}$ & $\begin{array}{c}\text { віднов- } \\
\text { ник }\end{array}$ & $\begin{array}{c}\text { вміст } \\
\text { віднов- } \\
\text { ника, } \\
\text { моль/л }\end{array}$ & & & & \\
\hline 1 & $\mathrm{NiSO}_{4}$ & - & $\mathrm{NaH}_{2} \mathrm{PO}_{2}$ & - & 16 & 34 & 28 & 97 \\
\hline 2 & $\mathrm{NiSO}_{4}$ & 0,22 & $\mathrm{NaH}_{2} \mathrm{PO}_{2}$ & 0,58 & 21 & 47 & 36 & 83 \\
\hline 3 & $\mathrm{NiSO}_{4}$ & 1,1 & $\mathrm{NaH}_{2} \mathrm{PO}_{2}$ & 2,9 & 32 & 60 & 37 & 82 \\
\hline
\end{tabular}

Примітка: ГЕМА: ПВП: $\mathrm{H}_{2} \mathrm{O}=80: 20: 25$ мас.ч., [ПБ] = 0,3 мас.\%, $T_{0}=50{ }^{\circ} \mathrm{C}$
За подальшого зростання вмісту компонентів ОВС у реакційній композиції істотно сповільнюється поліме-

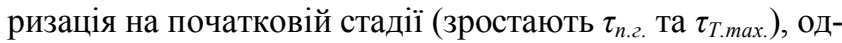
ночасно, майже не впливаючи на тривалість гель-ефекту та $T_{\text {макс }}$ (поз. 3). Можливо підвищення тривалості $\tau_{\text {n.г., }}$, $\tau_{\text {T.max. }}, \tau_{\text {o.г. }}$ та зменшення $T_{\text {макс }}$ пов'язано із стеричними чинниками через зростання у реакційному середовищі кількості катіонів та аніонів окисника та відновника, які блокують активні центри ПВП, перешкоджаючи утворенню КПЗ між ГЕМА та ПВП.

Окрім присутності у вихідній композиції ОВС, на швидкість полімеризації значно впливає склад ПМК зі збільшенням у композиції вмісту ПВП зростає її полімеризаційна здатність - зменшується час початку гелеутворення (табл. 4).

Табл. 4. Залежність параметрів гель-ефекту полімеризації від складу полімер-мономерної композиції

\begin{tabular}{|c|c|c|c|c|c|c|}
\hline $\begin{array}{c}\text { № } \\
\text { 3/п }\end{array}$ & \multicolumn{2}{|c|}{ Склад композиції, мас.ч. } & $\begin{array}{c}\tau_{\text {n.2., }}, \\
\text { ГЕМА }\end{array}$ & $\begin{array}{c}\tau_{\text {T.max. }}, \\
\text { ПВ }\end{array}$ & $\begin{array}{c}\tau_{\text {o.2., }} \\
\mathrm{xB}\end{array}$ & $\begin{array}{c}T_{\text {мaкс, }} \\
{ }^{\circ} \mathrm{C}\end{array}$ \\
\hline 1 & 90 & 10 & 20 & 61 & 50 & 87,3 \\
\hline 2 & 80 & 20 & 12 & 47 & 45 & 83,0 \\
\hline 3 & 70 & 30 & 12 & 34 & 26 & 70,2 \\
\hline
\end{tabular}

Примітка: $\mathrm{K} \mathrm{P}_{\mathrm{OBC}}=4: 1$ мас.ч.; [ПБ] $=0,3$ мас. $\% ;\left[\mathrm{NiSO}_{4}\right]=$

0,22 моль $/$ л; $T_{0}=50^{\circ} \mathrm{C}$

Збільшення у вихідній композиції кількості ПВП пришвидшує початок настання екзотермії, однак викли-

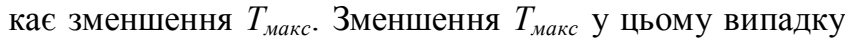
можна пояснити зменшенням вмісту у ПМК мономеру, який і викликає інтенсивне тепловиділення. Якщо під час полімеризації композиції складу ГЕМА: ПВП =90:10 максимальну температуру екзотермії спостері-

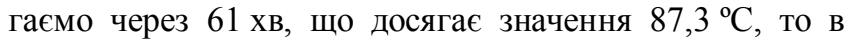
композиції, яка містить 30 мас.ч. ПВП, максимальна температура настає через 34 хв і становить $70,2^{\circ} \mathrm{C}$. ОПтимальною у цьому відношенні $\epsilon$ композиція із вмістом ПВП 20 мас.ч., для якої $T_{\text {макс }}=83{ }^{\circ} \mathrm{C}$, а $\tau_{\text {T.max. }}=47$ хв.

Залежно від початкової температури полімеризації, $T_{\text {макс }}$ системи закономірно збільшується у випадку зростання $\mathrm{T}_{0}$. Гель-ефект у цьому випадку настає значно швидше і виділення тепла реакційною системою $\epsilon$ інтенсивнішим - екзотермічний ефект проявляється на ранній стадії (табл. 5). Значно скорочується і область гель-ефекту. Аналогічну закономірність спостерігаємо і для композицій, в об'ємі яких одночасно з полімеризацією відбувається відновлення металу, хоча в присутності ОВС швидкість полімеризації завжди є меншою.

Табл. 5. Вплив початкової температури ( $\left.\mathrm{T}_{0}\right)$ на параметри гель-ефекту полімеризації ГЕМА/ПВП композицій

\begin{tabular}{|c|c|c|c|c|c|}
\hline № 3/ח & $T_{0},{ }^{\circ} \mathrm{C}$ & $\tau_{\text {n.2. }}, \mathrm{XB}$ & $\tau_{\text {T.max. }}, \mathrm{XB}$ & $\tau_{\text {o.2. }}, \mathrm{xB}$ & $T_{\text {макс }}{ }^{\circ} \mathrm{C}$ \\
\hline 1 & 50 & $16 / 21^{*}$ & $34 / 47$ & $29 / 36$ & $96,8 / 83$ \\
\hline 2 & 60 & $13 / 13$ & $20,5 / 26$ & $31 / 36$ & $116,1 / 108$ \\
\hline 3 & 70 & $6 / 9$ & $11,5 / 16$ & $21 / 22$ & $127,3 / 115,2$ \\
\hline
\end{tabular}

Примітка: ГЕМА: ПВП: $\mathrm{H}_{2} \mathrm{O}=$ 80:20:25 мас.ч.; $\left[\mathrm{NiSO}_{4}\right]=$ 0,22 моль/л; [ПБ] $=0,3$ мас.\% Пояснення: *у чисельнику - кінетичні параметри для полімеризації без ОВС; у знаменнику - параметри для полімеризації з одночасним відновленням

Підвищення початкової температури полімеризації звичайно сприяє зростанню швидкості процесів полімероутворення та металовідновлення. Однак через високу швидкість тепловиділення та погану теплопровідність полімеру відбувається теплове розширення та виникнення внутрішніх напружень, що є причиною появи тріщин в об'ємі зразка. 
Одним із методів здійснення полімеризації ГЕМА/ПВП композицій за низьких температур є полімеризація у присутності $\mathrm{FeSO}_{4}$ (Suberlyak, Grytsenko \& Kochubei, 2015). Під дією йонів металів змінного ступеня окиснення процес відбувається 3 високою швидкістю за кімнатної температури, на повітрі та завершується через 5-10 хв. Дослідженням кінетики кополімеризації ГЕМА з ПВП у присутності йонів металів змінного ступеня окиснення встановлено, що процес відбувається за йон-радикальним механізмом 3 чітко вираженим гельефектом та мінімальним індукційним періодом (Suberlyak, Skorokhoda \& Grytsenko, 2004). Теплові ефекти реакції не досліджували, хоча очевидно, що радикальна складова механізму полімеризації буде супроводжуватись виділенням реакційним середовищем тепла. Тому цікаво було дослідити кінетику тепловиділення під час полімеризації та встановити величину і початок настання $T_{\text {макс }}$. Результати досліджень підтверджують екзотермічну природу полімеризації ГЕМА/ПВП композицій під дією йонів феруму (II) (табл. 6, поз. 1). Однак максимальна температура екзотермії становить $52{ }^{\circ} \mathrm{C}$, хоча i наступає через 10 хв. Водночас, відповідно до попередніх досліджень, встановлено можливість кополімеризації ГЕМА з ПВП за кімнатної температури в присутності комбінованої ініціювальної системи $\mathrm{FeSO}_{4} /$ ПБ (Grytsenko, Gnatchuk \& Suberlyak, 2013). Встановлено (див. табл. 6, поз. 2), що полімеризація ГЕМА в присутності ПВП під дією ПБ за температури $50{ }^{\circ} \mathrm{C}$ характеризується максимальною температурою екзотермії $118^{\circ} \mathrm{C}$, яка настає через 27 хв від іï початку. Використанням комбінованої ініціюювальної системи $\mathrm{FeSO}_{4} /$ ПБ для полімеризації ГЕМА/ПВП композицій досягнуто $T_{\text {макс }}=83{ }^{\circ} \mathrm{C}$ за, порівняно, короткий проміжок часу 33 хв та в умовах початкової кімнатної температури (див. табл. 6, поз. 3).

Табл. 6. Залежність параметрів гель-ефекту полімеризації від типу ініціювальної системи

\begin{tabular}{|c|c|c|c|c|c|c|}
\hline $\begin{array}{c}\text { № } \\
\text { 3/П }\end{array}$ & $\begin{array}{c}\text { Ініціюваль- } \\
\text { на система }\end{array}$ & ОВС & $\begin{array}{c}\tau_{\text {n.z., }} \\
\text { Хв }\end{array}$ & $\begin{array}{c}\tau_{\text {T.max., }} \\
\text { хв }\end{array}$ & $\begin{array}{c}\tau_{\text {o.z., }} \\
\text { хв }\end{array}$ & $\begin{array}{c}T_{\text {макс }} \\
{ }^{\circ} \mathrm{C}\end{array}$ \\
\hline 1 & $\mathrm{FeSO}_{4}$ & - & 0,3 & 10 & 22,7 & 52 \\
\hline $2 *$ & ПБ & - & 12 & 26 & 27 & 121 \\
\hline 3 & $\mathrm{FeSO}_{4} /$ ПБ & - & 2 & 33 & 44 & 83 \\
\hline 4 & $\mathrm{FeSO}_{4} /$ ПБ & $\mathrm{NiSO}_{4} / \mathrm{NaH}_{2} \mathrm{PO}_{2}$ & 5 & 47 & 51 & 76 \\
\hline
\end{tabular}

Примітка: ГЕМА: ПВП: $\mathrm{H}_{2} \mathrm{O}=8: 2: 1$ мас.ч., $T_{0}=25^{\circ} \mathrm{C}$, [ $\left.\mathrm{FeSO}_{4}\right]$ $=0,01$ мас. $\%$, [ПБ $]=0,3$ мас. $\%$ Пояснення: ${ }^{*} T_{0}=50^{\circ} \mathrm{C}$.

Отриманий ефект використано для полімеризації ПВП/ГЕМА композиції у присутності ОВС (див. табл. 6, поз. 4). Максимальна температура екзотермії у цьому випадку становить $76^{\circ} \mathrm{C}$. Відновлення металів гіпофосфітами інтенсивно відбувається за температури 90-95 ${ }^{\circ} \mathrm{C}$ (Yavors'kyy, Kuntyy \& Khoma, 2000). Водночас досліджено, що присутність у вихідній композиції ПВП та використання каталізатора відновлення $\mathrm{AgNO}_{3} \mathrm{y}$ лужному середовищі забезпечують здійснення реакції за $60-70{ }^{\circ} \mathrm{C}$ (Grytsenko et al., 2016). Отже, температура, до якої нагрівається реакційне середовище під час полімеризації ГЕМА/ПВП композицій, $є$ достатньою для перебігу хімічної реакції відновлення $\mathrm{Ni}^{2+}$.

Встановлені в роботі часові та температурні параметри полімеризації, а також основні чинники, від яких ці параметри залежать, дадуть змогу надалі обгрунтувати технологічні параметри процесу одержання металонаповнених кополімерів ГЕМА з ПВП.
Висновки. За допомогою термометричного методу досліджено кінетичні параметри полімеризації ГЕМА/ПВП композицій з одночасним відновленням $\mathrm{Ni}^{2+}$. Час настання гель-ефекту та максимальна температура екзотермії здебільшого залежать від складу вихідної композиції, вмісту розчинника, початкової температури полімеризації, концентрації окисника та відновника. Завдяки використанню комплексного ініціатора, який складається зі сульфату заліза (II) та пероксиду бензоїлу, встановлено можливість здійснення полімеризації ГЕМА/ПВП композицій за кімнатної температури та 3 максимальною температурою екзотермії. Тепло, яке виділяється у процесі полімеризації, є джерелом енергії, необхідної для хімічного відновлення $\mathrm{Ni}^{2+}$, що забезпечує зменшення температури відновлення та початкової температури полімеризації.

\section{Перелік використаних джерел}

Grytsenko, O. M., Gnatchuk, N. M., \& Suberlyak, O. V. (2013). Effect of initiating system the structure and characteristics of hydrogels on the basis of polyvinylpyrrolidone copolymers. Eastern-European Journal of Enterprise Technologies, 5/8(65), 59-63. [In Ukrainian].

Grytsenko, O., Pokhmurska, A., Suberliak, S., Kushnirchuk, M., Panas, M., Moravskyi, V., \& Kovalchuk, R. (2018). Technological features in obtaining highly effective hydrogel dressings for medical purposes. Eastern-European Journal of Enterprise Technologies, 6, 6(96), 6-13. https://doi.org/10.15587/1729-4061.2018.150690

Grytsenko, O., Suberlyak, O., Moravskyi, V., \& Gayduk, A. (2016). Investigation of nickel chemical precipitation kinetics. Eastern-European Journal of Enterprise Technologies, 1/6(79), 26-31. [In Ukrainian]. https://doi.org/10.15587/1729-4061.2016.59506

Korolyov, G. V., Pavlov, B. V., \& Berlin, A. A. (1959). Termometriya kak metod izucheniya kinetiki polimerizatsii. Polymer Science, 1(9), 1396-1402. [In Russian].

Nicolais, L., \& Carotenuto, G. (2004). Metal-Polymer Nanocomposites. John Wiley \& Sons.

Nikolayev, A. F. (1974). Synthetic polymers and plastics based on them. Moscow: Chemistry. [In Russian].

Schexnailder, P., \& Schmidt, G. (2009). Nanocomposite polymer hydrogels. Colloid and Polymer Science, 287(1), 1-11. https://doi.org/10.1007/s00396-008-1949-0

Suberlyak, O. V., Kurylo, M. S., \& Sheketa, M. L. (1982). Termometricheskiye issledovaniya blochnoy trekhmernoy polimerizatsii kompozitsiy na osnove 2-HEMA. (Ser. Chemistry, Technology of Substances and their Application). Bulletin of the Lviv Polytechnic Institute, 163, 41-43. [In Russian].

Suberlyak, O. V., Skorokhoda, V. Y., \& Grytsenko, O. M. (2000). Naukovi aspekty rozroblennya tekhnolohiyi syntezu hidrofil'nikh kopolimeriv PVP. Issues of Chemistry and Chemical Technology, 1, 236-238. [In Ukrainian].

Suberlyak, O., \& Skorokhoda, V. (2018). Hydrogels Based on Polyvinylpyrrolidone Copolymers. Hydrogels. InTechOpen, 136214. https://doi.org/10.5772/intechopen.72082.

Suberlyak, O., Grytsenko, O., \& Kochubei, V. (2015). The role of Fe$\mathrm{SO}_{4}$ in the obtaining of polyvinylpirolidone copolymers. Chemistry \& Chemical Technology, 9(4), 429-434. https://doi.org/10.23939/chcht09.04.429

Suberlyak, O., Skorokhoda, V., \& Grytsenko, O. (2004). Complex PVP-Me ${ }^{\mathrm{n}+}-$ active catalyst of vinyl monomers polymerization. $M a-$ terialy polimerowe i ich przetworstwo, 140-145. Wyd. politechniki Czestohowskiej.

Yavorskyy, V. T., Kuntyy, O. I., \& Khoma, M. S. (2000). Elektrokhimichne napylennya metalevykh, konversiynikh ta kompozytsiynykh pokryttiv. Lviv: Lvivska politekhnika. [In Ukrainian]. 


\section{THERMOMETRIC INVESTIGATIONS OF 2-HYDROXYETHYLMETHACRYLATE POLYMERIZATION AT THE PRESENCE OF POLYVINYLPYRROLIDONE WITH SIMULTANEOUS NICKEL IONS REDUCTION}

The kinetics of heat release during the processes of 2-hydroxyethyl methacrylate (HEMA) polymerization in the presence of polyvinylpyrrolidone (PVP) and the copolymerization of HEMA with PVP with simultaneous reduction of $\mathrm{Ni}^{2+}$ has been investigated. Nickel sulphate/sodium hypophosphite redox system in alkaline medium was used for $\mathrm{Ni}^{2+}$ reduction. The kinetic regularities of polymerization have been evaluated by thermometric method. The temperature change of the reaction medium during polymerization has been investigated by means of developed equipment, based on the reactor with properties like adiabatic one. The characteristic parameters that correspond to the time of gel formation, the time of exothermic maximum temperature reach, the range of gel effect and maximum temperature of the exotherm are identified on the obtained thermometric curves. It is determined that in the case of HEMA/PVP compositions, polymerization in the presence of benzoyl peroxide occurs with high rate already at 50 ${ }^{\circ} \mathrm{C}$. The time of the gel effect start and maximum exothermic temperature mainly depend on the initial composition formula, solvent content, initial polymerization temperature, and also the simultaneous reduction of $\mathrm{Ni}^{2+}$ in the polymerization process. The presence of even a small content of oxidizing agent and reducing agent causes an increase of the time of gel formation start, time of maximum exothermic temperature reach and a decrease of the maximum exothermic temperature. It is determined that use of benzoyl peroxide in combination with iron (II) sulfate for initiating of HEMA copolymerization with PVP enables the process to be performed at room temperature and with a maximum exothermic temperature, which provides chemical reduction of $\mathrm{Ni}^{2+}$. The time and temperature parameters of polymerization determined in the work, as well as the main factors on which these parameters depend, will provide an opportunity to substantiate the technological parameters of metal-filled HEMA/PVP copolymers obtaining.

Keywords: exothermic polymerization; exothermic temperature; polymerization kinetics; gel effect; metal-filled polymer composites. 